\title{
Study on English Learning Evaluation System in Higher Vocational College Oriented at Employment
}

\author{
Yanping YANG \\ Liuzhou Railway Vocational Technical College, Liuzhou, 545007, China \\ Email: 475382511@qq.com
}

Keywords: higher vocational college; English learning evaluation; Employment-oriented

\begin{abstract}
Learning evaluation mechanism can verify whether the vocational college students' learning outcomes reach the educational objectives, and it is also the measurement of successful employment. However, there exists lots of problems in the evaluation of traditional English learning in higher vocational colleges. This paper gives ideas on the reform of students' ability evaluation oriented at employment.
\end{abstract}

\section{Introduction}

Employment has become a big problem for the graduates from higher vocational college. Although the Ministry of Education in China has pointed out that the reform of higher vocational education should be oriented to "employment-oriented", the current English teaching mode and evaluation in higher vocational college still copy or follow regular higher education . Teaching evaluation system is an important part of English course and plays a very important role in higher vocational education. It is the basis to ensure the teaching quality and improve the teaching management. It also can be an effective means for the students to adjust their learning methods and improve their learning efficiency. However, the evaluation of English learning in higher vocational college can not fully reflect the students' learning ability, neither achieve the goal of cultivating English application ability.

\section{Existing problems in evaluation of English learning at higher vocational college}

\subsection{Incomplete evaluation}

In traditional public English teaching, higher vocational college evaluates students' learning effect only by midterm examination, final examination or practical English test, which forms the integration of teaching and examination as well as fixed mode of "All are determined by a piece of test paper”. A single closed-book exam lays particular emphasis on students' grasp and application of knowledge, which lacks systematic research on professional skills and ability evaluation. Thus, students' English application skills can not be evaluated comprehensively, including listening, speaking, reading, writing and translating.

\subsection{The teaching process lacks other process evaluations}

The scale of higher vocational education in China has developed rapidly in recent years, so the number of the higher vocational colleges and students has greatly increased. However, there is no appropriate and complete learning evaluation system, and the English learning evalation still follow the traditional way, which deviates from the ability-oriented vocational education. The characteristics and nature of course as well as students' personality development can not be fully realized. Except for vocational operation skills, the objectives of higher vocational education also enable students to grasp general skills. However, written test can not timely and objectively evaluate students' qualities which will be cultivated in teaching process, such as learning ability, practical ability, innovative spirit, team spirit, etc..

\subsection{Insufficient evaluation of employment ability}

PRETCO(Practical English Test for Colleges), approved by the Chinese Ministry of Education, is regarded as an important proof by every college and student. Lots of employers require the 
employee to have certificate of PRETCO. However, such certificate can not well represent employee's language ability in the process of talent assessment. The emphasis on pass rate of PRETCO and the certificate in vocational college makes the teachers' teaching activities focus on PRETCO. One-sided emphasis on level test contributes to teachers' and students' utilitarian psychology, which may destroy the natural approach and normal step of the study, repeating the past exam-oriented teaching. Undoubtedly, this goes against the objective of higher vocational education - cultivating talents to service for production, operation and management. The ultimate objective of public English teaching in higher vocational college should cultivate students' practical ability, namely cultivating students' ability to use foreign language to deal with daily work. However, all of these abilities can not be illustrated by a certificate of PRETCO.

The examination and evaluation system of public English teaching in higher vocational college mainly becomes an indicator to evaluate student scholarship, and its functions of guiding teaching reform and stimulating students' quality cultivation have not been played completely. Besides, there exist obvious defects in comprehensive feedback on teaching effect, urging teachers to analyze the gap and deficiency in teaching, promoting reform of teaching methods and encouraging students' comprehensive development.

\section{Employment-oriented reform ideas of student evaluation}

\subsection{Strengthening evaluation of English application ability}

The reform of public English teaching effect in higher vocational college and the improvement of students' adaptability to employment should focus on not only test scores, but also students' grasp of actual operation skills and social acceptance of higher vocational graduates' application ability. Therefore, the evaluation of higher vocational college students' academic record should be changed from only written test to a comprehensive evaluation of English application ability, breaking the traditional fixed mode of "All are determined by a piece of test paper" and emphasizing the integration of writing and speaking. Comprehensive appraisal of listening, speaking, writing and translating can help students pay more attention to cultivating their language application ability and get rid of exam-oriented learning mode.

The test in a semester should be divided into two parts. One is test for basic knowledge, which tests students' foundation of linguistic knowledge as well as their grasp of textbook knowledge. The other is test for application ability, which mainly tests students' grasp of English application ability, and this part can also be divided into test for special ability taken by students irregularly according to teaching progress. The form of test can be diversified, such as reading, making a dialogue, speech, interpretation, discussion, contest, etc.. Teachers can carry out these forms flexibly in classroom teaching procedure and then give score accordingly. Various skill competitions that students participate in can be used in their teaching evaluation according to their performance, which can encourage students to learn more and use them as much as possible. At the end of the term, the performance of each application ability should be summed up and included in final exam by percentage.

As for the students attending English practical teaching, they should accept teaching quality evaluation of " $2+1$ " talents training mode formulated by college and enterprise. In the practice, the enterprise makes various evaluations on students' English skills and actual operation, and teachers include such evaluation proportionally in final exam. Such evaluation can give full play to the directionality and adaptability of employment-oriented public English teaching in higher vocational college. This kind of evaluation results will be the most powerful explanation of students' English application ability when they are searching for a job.

\subsection{Evaluation of comprehensive quality of employment}

Employment-oriented higher vocational education is a comprehensive quality education, which not only cultivates students' professional quality to learn how to do and have a better job, but also cultivates students' relevant professional quality to learn how to behave. College English teaching should attach more importance to the evaluation of employment quality, and also put the employment 
quality training into the talents training plan. Except for teaching students' English knowledge and skills, teachers also should pay attention to students' performance in daily teaching activity, such as their language expression and collaboration ability, thinking and analysis ability, innovation ability, dedication spirit, decent manners, etc.. All of these are required in students' job career. In teaching process, teachers should give praise when students perform well in these aspects. In contrast, teachers should pay attention to helping students improve. In addition, teachers should record students' performance by score and include them in final exam. Such method can help teachers get to know the goal of different students' quality development. Meanwhile, it can enable students to have a comprehensive understanding of themselves, stimulate fighting spirit, establish confidence, improve professional quality and lay foundation for higher vocational talents.

\subsection{Implementation of both English level certificate and certificate of professional English proficiency}

According to the objectives of higher vocational education, the public English teaching can only implement quality teaching and put the teaching emphasis on cultivating students' application ability. Therefore, teachers and students must deal with the relation between level test and English application skills to avoid negative influence caused by one-sided emphasis on level test. The English level test should be regarded as only a kind of evaluation method, and teachers can make scores as the final achievement of the course to include in the credit. If students can obtain English level certificate before finishing learning this course, they will be allowed to have an early end to this course, because their basic ability tends to be consistent with the social requirement.

The standards for English teaching at higher vocational school are practical and sufficient to use. In order to meet the demands of the market and follow the employment orientation, colleges can also encourage the students to participate in professional English proficiency test. The distinctive certificate of professional English proficiency in each industry has the adaptability of this industry, which is an appraisal test for the students' professional skills and abilities. It will be more professional and convincing when graduates have such certificate of professional English proficiency when searching for a job. So in the pubic English teaching in higher vocational college, if students can obtain corresponding certificate of professional English proficiency, they should also be regarded as being qualified in this course.

\section{Conclusion}

Employment-oriented public English teaching in higher vocational college should change one-sided emphasis on traditional practicability and utilitarian and cultivate all-round development of high-quality talents who both have skillful English application ability and high professional quality. Thus, the less significant status of public English course as a foundation course in higher vocational college will be greatly improved.

\section{References}

[1] He Peifeng. Study on English Test and English Ability Evaluation System in Higher Vocational College [J]. Education and Vocation, 2005 (7).

[2] Yan Huiying. Study on Higher Vocational English Evaluation System Based on Vocational Graduates’ English Application Situation [J]. Examinations, 2007 (27).

[3] Zhao Jinling. English Teaching Oriented at Employment in Higher Vocational College [J]. Examinations, 2009 (38).

[4] Zhao Zhiying. English Teaching Modularization in Higher vocational College Oriented at Employment [J]. Crazy English Teachers, 2008 (4).

[5] Li Liuying. English Test Reform in Higher Vocational College from soical needs perspective [J]. School English, 2012 (10). 